This item was submitted to Loughborough's Research Repository by the author.

Items in Figshare are protected by copyright, with all rights reserved, unless otherwise indicated.

\title{
An intermolecular hydroamination of allenamides with arylamines catalyzed by cationic $A u(I)$ salts
}

PLEASE CITE THE PUBLISHED VERSION

http://dx.doi.org/10.1021/jo101035n

PUBLISHER

(C) American Chemical Society

VERSION

AM (Accepted Manuscript)

LICENCE

CC BY-NC-ND 4.0

\section{REPOSITORY RECORD}

Hill, Anthony W., Mark R.J. Elsegood, and Marc C. Kimber. 2019. "An Intermolecular Hydroamination of Allenamides with Arylamines Catalyzed by Cationic Au(i) Salts”. figshare. https://hdl.handle.net/2134/13947. 
This item was submitted to Loughborough's Institutional Repository (https://dspace.lboro.ac.uk/) by the author and is made available under the following Creative Commons Licence conditions.

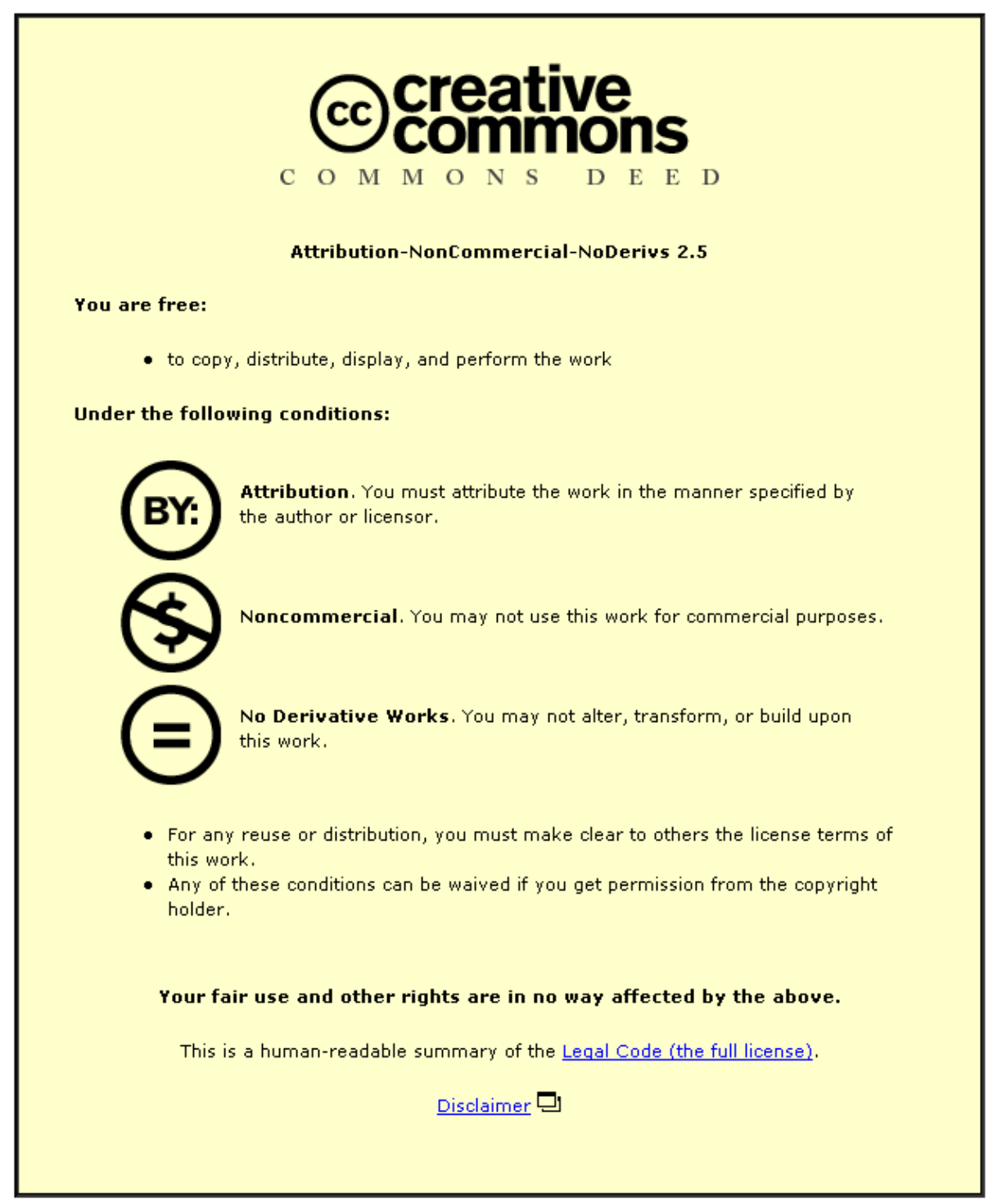

For the full text of this licence, please go to: http://creativecommons.org/licenses/by-nc-nd/2.5/ 


\section{An Intermolecular Hydroamination of Allenamides Catalysed by Cationic Au(I) Salts}

\author{
Anthony W. Hill, Mark R. J. Elsegood and Marc C. Kimber* \\ Department of Chemistry, Loughborough University \\ Leicestershire, LE11 3TU, UK \\ M.C.Kimber@lboro.ac.uk
}

RECEIVED DATE (will be automatically inserted after manuscript is accepted).

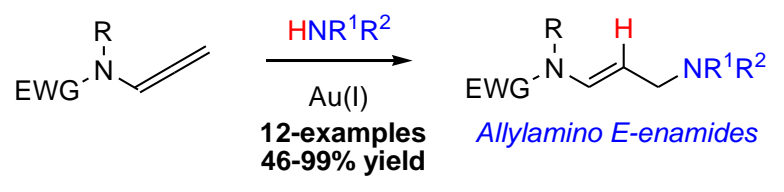

An intermolecular hydroamination of allenamides has been achieved under mild $\mathrm{Au}(\mathrm{I})$ catalysis conditions delivering allylamino $E$-enamides stereoselectively and in high yield. The reaction is made possible via a convenient method for conjugated $N$-acyliminium formation.

The addition of the N-H bond over alkene and alkyne $\pi$ systems, the hydroamination transformation, represents a powerful method for the introduction of the amine functionality. ${ }^{1}$ Such transformations give access to a range of valuable nitrogen containing building blocks such as amines, imines and enamines. Within this group of reactions the intermolecular hydroamination of allenes has become increasingly important due to the regiochemical factors in such transformations. Allenes (1) can undergo either Markovnikov or anti-Markovnikov addition, giving rise to allylamines (2a) or imines (2b) (Scheme 1). This first group of substrates, allylamines, are vital synthetic building blocks since they are contained within a number of important biological systems and are key intermediates in organic synthesis. $^{2}$

A number of transition metal approaches towards the hydroamination of allenes have been reported, including the use of $\mathrm{Zr}$ (anti-Markovikov), $\mathrm{Hg}$ (Markovnikov), $\mathrm{Pt}$ (Markovnikov) and Pd (Markovnikov) salts. ${ }^{3}$ Additional to

(1) For reviews on hydroamination see (a) Müller, T. E.; Hultzsch, K. C.; Yus, M.;Foubelo, F.; Tada, M. Chem. Rev. 2008, 108, 3795. (b) Widenhoefer, R. A.; Han, X. Eur. J. Org. Chem. 2006, 4555. Severin, R.; Doye, S. Chem. Soc. Rev 2007, 36, 1407. (c) Hong, S.; Marks, T. J. Acc. Chem. Res. 2004, 37, 673. (d) Hartwig, J. F. Pure Appl. Chem. 2004, 76, 507. (e) Chianese, A. R.; Lee, S. J.; Gagné, M. R. Angew. Chem. 2007, 119, 4118; Angew. Chem. Int. Ed. Engl. 2007, 46, 4042. (f) Alonso, F.;Beletskaya, I. P.; Yus, M. Chem. Rev. 2004, 104, 3079. (g) Beller, M.;Seayad, J.; Tillack, A.; Jiao, H. Angew. Chem. 2004, 116, 3448; Angew. Chem. Int. Ed. Engl. 2004, 43, 3368.

(2) Johannsen, M.; Jørgensen, K. A. Chem. Rev. 1998, 98, 1689

(3) Walsh, P. J.; Baranger, A. M.; Bergman, R. G. J. Am. Chem. Soc. 1992, 114, 1708; Johnson, J. J.; Bergman, R. G. J. Am. Che. Soc. 2001, 123 2924; Ayinla, R. O.; Schafer, L. L. Inorg, Chim., Acta 2006, 359, 3097; De Renzi, A.; Ganis, P.; Panunzi, A.; Vitagliano, A. J. Am. Chem. Soc. 1980, 105, 1722; Besson, L.; Goré, J.; Cazes, B. Tetrahedron Lett. 1995, 36, 3857; these transition metals, Au salts have proved to particularly attractive in hydroamination reactions due to their low toxicity and increased stability to moisture and air. ${ }^{4}$ Consequently, a number of groups have utilised $\mathrm{Au}$ salts in these transformation to great effect. ${ }^{1 \mathrm{~b}, 5}$

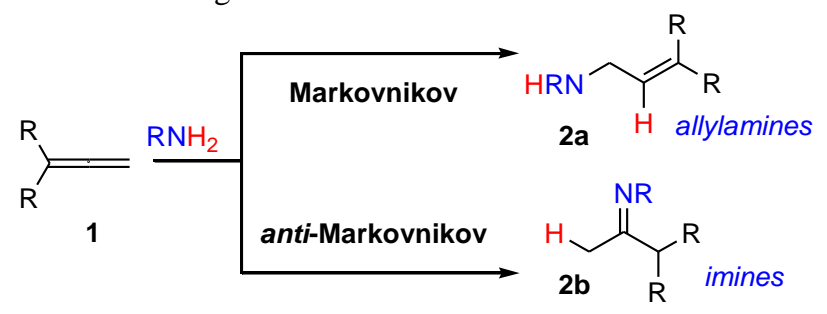

SCHEME 1. The hydroamination of allenes.

Recently, we reported $^{6}$ the first intermolecular hydroarylation of allenamides ${ }^{7}$ with electron rich aromatics using an $\mathrm{Au}(\mathrm{I})$ catalyst to give the corresponding enamides. Enamides $^{8}$ are a class substrates that have become particularly topical due to their use in the construction of heterocycles, chiral amines and their presence in a number of natural product frameworks. ${ }^{9}$ This transformation was high yielding

Al-Masum, M.; Meguro, M.; Yamamoto, Y. Tetrahedron Lett. 1997, 38, 6071.

(4) For reviews on Au catalysis see (a) Arcadi, A. Chem. Rev. 2008, 108 , 3266. (b) Hashmi, A. S. K. Chem. Rev. 2007, 107, 3180. (c) Hashmi, A. S. K.; Rudolph, M. Chem. Soc. Rev. 2008, 37, 1766.

(5) Selected $\mathrm{Au}$ catalysed hydroamination methods (a) Zeng, X Soleilhavoup, M.; Bertrand, G. Org. Lett. 2009, 11, 3166; (b) Kinder, R. E.; Zhang, Z.; Widenhoefer, R. A. Org. Lett. 2008, 10, 3157; (c) Duncan, A. N.; Widenhoefer, R. A. Synlett 2010, 419; (d) Nishina, N.; Yamamoto, Y. Synlett 2007, 1767; (e) Lavallo, V.; Donnadieu, G. D. B; Soleilhavoup, M.; Bertrand. G. Angew. Chem. 2008, 120, 5302; Angew. Chem. Int. Ed. Engl.. 2008, 47, 5334; (f) Nishina, N.; Yamamoto, Y. Angew. Chem. 2006, 118, 3392; Angew. Chem. Int. Ed. Engl. 2006, 45, 3314.

(6) Kimber, M. C. Org. Lett. 2010, 12, 1128

(7) (a) For a perspective on allenamides in synthesis see, Wei, L. -L.; Xiong, H.; Hsung, R. P. Acc. Chem. Res. 2003, 36. For the use of allenamides in (b) radical cyclisation, Shen, L.; Hsung, R. P. Org. Lett. 2005, 7, 775. (c) tandem/epoxidations/cycloadditions, Huang, J.; Hsung, R. P. J. Am. Chem. Soc. 2005, 127.,50; (d) Pauson Khand cyclisations, Anorbe, L.; Poblador, A.; Dominguez, G.; Perez-Castells, J. Tetrahedron Lett. 2004, 45, 4441. González-Gómez, Á.; Añorbe, L.; Poblador, A.; Domínguez, G.; PérezCastells, J. Eur. J. Org. Chem. 2008, 1370; Xiong, Z. H.; Hsung, R. P.; Wei, L. -L.; Berry, C. R.; Mulder, J. A.; Stockwell, B. Org. Lett. 2000, 2, 2869; [4+2] and [4+3] cycloadditions, Berry, C. R.; Hsung, R. P. Tetrahedron 2004, 60, 7629; Song, Z.; Hsung, R. P.; Lu, T.; Lohse, A. G. J. Org. Chem. 2007, 72, 9722; Xiong, H.; Huang, J.; Ghosh, S. K.; Hsung, R. P. J. Am. Chem. Soc. 2003, 125, 12694; Lohse, A. G.; Hsung, R. P. Org. Lett. 2009, 11, 3430. (e) acid catalysed cyclisations and rearrangments, Hayashi, R.; Hsung, R. P.; Feltenberger, J. B.; Lohse, A. G. Org. Lett. 2009, 11, 2125; Berry, R.; Hsung, R. P.; Antoline, J. E.; Petersen, M. E.; Challeppan, R.; Nielson, J. A. J. Org. Chem. 2005, 70, 4038; (f) palladium mediated transformations, Beccalli, E. M.; Broggini, G.; Clerici, F.; Galli, S.; Kammerer, C.; Rigamonti, M.; Sottocornola, S. Org. Lett. 2009, 11, 1563; Fuwa, H.; Sasaki, M. Org. Biomol. Chem. 2007, 5, 2214; (g) cyclopropanations, Lu, T.; Hayashi, R.; Hsung, R. P.; DeKorver, K. A.; Lohse, A. G.; Song, Z.; Tang, Y. Org. Biomol. Chem. 2009, 7, 3331; (h) base catalysed $\mathrm{CO}_{2}$ capture, Chen, C. G.; Fu, C.; Ma, S. Org. Lett. 2009, 11, 2900; (h) Au mediated transformations, Hyland, C. J. T.; Hegedus, L. S.; J. Org. Chem. 2006, 71, 8658; Manzo, A. M.; Perboni, A. D.; Broggini, G.; Rigamonti, M. Tetrahedron Lett. 2009, 50, 4696.

(8) For a review of the synthetic utility of enamides see, Carbery, D. R. Org. Biomol. Chem. 2008, 6, 3455.

(9) Davyt, D.; Entz, W.; Fernandez, R.; Mariezcurrena, R.; Mombru, A. W.; Saldana, J.; Domınguez, L.; Coll, J.; Manta, E. J. Nat. Prod. 1998, 61, 1560. Gallier, F.; Hussain, H.; Martel, A.; Kirschning, A.; Dujardin, G. Org. Lett. 2009, 11, 3060. Sibi, M. P.; Asano, Y. J. Am. Chem. Soc. 2001, 123, 
for most substrates and gave exclusively the $E$-enamide. Importantly, unlike many of the methods ${ }^{10}$ for enamide preparation, the reaction required no exclusion of air and moisture and the reaction was extremely facile.

While there are reported methods for the Au catalysed intermolecular hydroamination of allenes to give allyl amines within the literature, ${ }^{5}$ methods for the intermolecular hydroamination of allenamides remains untouched to our knowledge. Whereas the hydroamination of allenes delivers synthetically useful allylamines, the intermolecular Markovnikov addition of an N-H bond over an allenamide 3 would deliver an allylamino enamide $\mathbf{4}$, a substrate that would contain both an allyl amine and an enamide within the one synthetic framework (Scheme 2). Therefore, in this communication we would like to share our results of the first intermolecular hydroamination of allenamides using aniline derivatives under our $\mathrm{Au}(\mathrm{I})$ catalytic conditions.

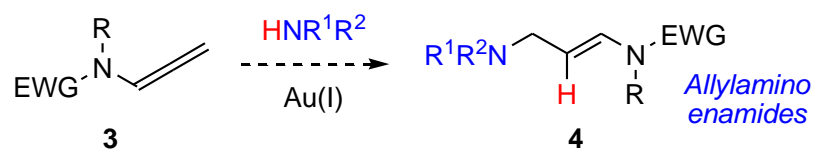

SCHEME 2. The proposed hydroamination of allenamides.

The allenamides used for this study are shown below in Scheme 3. Cyclic allenamides $\mathbf{5 a}$ and $\mathbf{5 b}$ were synthesised using an adapted method of Heaney, ${ }^{11}$ and the acyclic allenamide 7 was synthesised via initial amide formation followed by base catalysed rearrangement. ${ }^{12}$

Our starting point would be the conditions used for our hydroarylation protocol. ${ }^{6}$ Therefore a solution of allenamide 5a (1.00 equiv.) and aniline 8a (1.05 equiv.) in $\mathrm{CH}_{2} \mathrm{Cl}_{2}$ was treated with a catalytic amount (5 mol\%) of cationic $\mathrm{Au}(\mathrm{I}) \mathrm{PPh}_{3} \mathrm{OTf}$ generated from $\mathrm{AuClPPh}_{3}$ and $\mathrm{AgOTf}$ at room temperature (Scheme 4). To our delight the hydroaminated

9708. Tan, N. -H.; Zhou, J. Chem. Rev. 2006, 106, 840. Xiao, D.; Zhang, Z.; Zhang, X. Org. Lett. 1999, 1, 1679. Yet, L. Chem. Rev. 2003, 103, 4283.

(10) Methods for enamide synthesis, (a) organocuprate addition to isocyanates, Snider, B. B.; Song, F. Org. Lett. 2000, 2, 407; (b) acylation of imines, Boeckman, R. K.; Goldstein, S. W.; Walters, M. A. J. Am. Chem. Soc. 1988, 110, 8250; (c) $\mathrm{N}$-acylation/Peterson elimination, Fürstner, A.; Brehm, C.; Cancho-Grande, Y. Org. Lett. 2001, 3, 3955; (d) Pd-Cu catalysed C-N bond formations, Klapars, A.; Campos, K. R.; Chen, C.; Volante, R. P. Org. Lett. 2005, 7, 1185; Brice, J. L.; Meerdink, J. E.; Stahl, S. S. Org. Lett. 2004 6, 1845; Wallace, D. J.; Klauber, D. J.; Chen, C.; Volante, R. P. Org. Lett. 2003, 5, 4749; Cesati III, R. R.; Dwyer, G.; Jones, R. C.; Hayes, M. P.; Yalamanchili, P.; Casebier, D. S. Org. Lett. 2007, 9, 5617; Bolshan, Y.; Batey, R. A. Angew. Chem. 2008, 120, 2139; Angew. Chem. Int. Ed. Engl. 2008, 57, 2109; Chemler, S. R.; Fuller, P. H. Chem. Soc. Rev 2007, 36, 1153 (e) Fe, Ru, Ru methods see, Stille, J. K.; Becker, Y. J. Org. Chem. 1980, 45 2139; (f) for organometallic additions to ynamides, Gourdet, B.; Rudkin, M E.; Watts, C. A.; Lam, H. W. J. Org. Chem. 2009, 74, 7849; (g) for Heck coupling strategies, Vallin, K. S. A.; Zhang, Q.; Larhed, M.; Curran, D. P.; Hallberg, A. J. Org. Chem. 2003, 68, 6639; Harrison, P.; Meek, G. Tetrahedron Lett. 2004, 45, 9277; (h) for co-oligomerization of N-vinyl amides see, Tsujita, H.; Ura, Y.; Matsuki, S.; Wada, K.; Mitsudo, T.; Kondo, T. Angew. Chem. 2007, 119, 5252; Angew. Chem. Int. Ed. Engl. 2007, 46, 5160; (i) for oxidative Pd catalysed conjugate addition, Lee, J. M.; Ahn, D. S.; Jung, D. Y.; Lee, J.; Do, Y.; Kim, S. K.; Chang, S. J. Am. Chem. Soc. 2006, 128,12954

(11) Heaney, H.; Ley, S. V. J. Chem. Soc., Perkin Trans. 1 1973, 499.

(12) Wei, L. -L.; Mulder, J. A.; Xiong, H.; Zificsak, C. A.; Douglas, C. J.; Hsung, R. P. Tetrahedron 2001, 57, 459. product 9a was isolated in $86 \%$ yield after chromatography. The enamide was obtained exclusively as the $E$-isomer, and the addition of the $\mathrm{N}-\mathrm{H}$ bond to the activated allenamide gave the Markovnikov product.

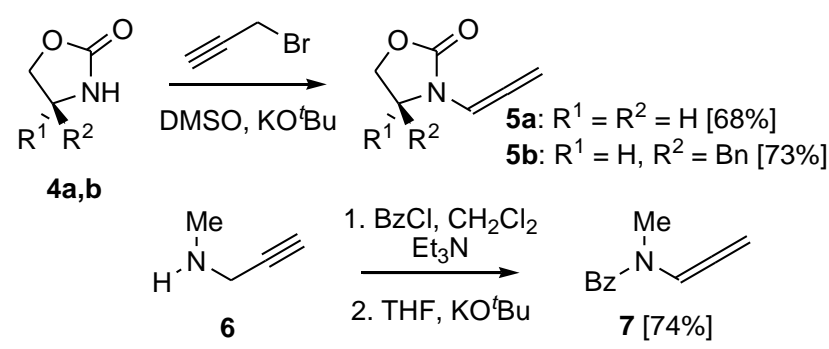

SCHEME 3. Preparation of allenamides $\mathbf{5 a}, \mathbf{b}$ and 7.

A comparable yield of $84 \%$ was also obtained using 5 mol\% of the $\mathrm{Au}(\mathrm{I})$ complex, $\mathrm{AuPPh}_{3}\left(\mathrm{NTf}_{2}\right)$. The stereochemistry of the $E$-enamide double bond was supported by a combination of ${ }^{1} \mathrm{H}$ and ${ }^{13} \mathrm{C}$ NMR, IR spectroscopy (coupling constant $14.0 \mathrm{~Hz}$ and $1673 \mathrm{~cm}^{-1}$ ) and single crystal X-ray analysis. ${ }^{13}$

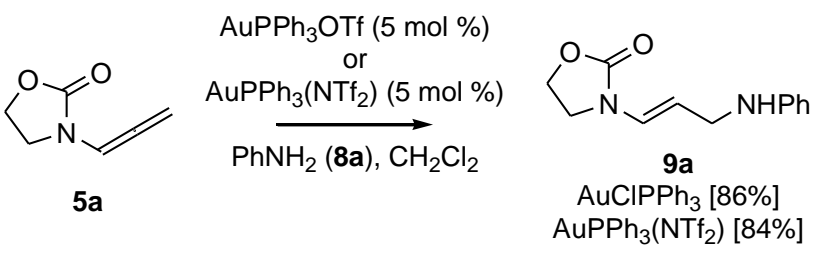

SCHEME 4. Hydroamination of allenamide 5a.

The applicability of this protocol was then further explored, the results of which are summarised in Table 1. Haloanilines 8b and 8f successfully added to the allenamide giving the enamides 9b and 9f in good yield (entries 1 and 5). Introduction of an electron withdrawing ethyl ester para to the $\mathrm{NH}_{2}$ gave the enamide 9c in a moderate $61 \%$ yield (entry 2 ), while a nitro group at the ortho position was tolerated and gave the enamide 9d quantitatively (entry 3). 2,5-Dimethyl aniline $\mathbf{8 e}$ and 3-methoxyaniline $\mathbf{8 g}$ both successfully added to the activated allenamide to give the hydroaminated products 9e and 9g, respectively (entries 4 and 6). Unfortunately, pentafluoroaniline $\mathbf{8 h}$ failed to add to the activated allenamides, presumeably due to its low nucleophilicity (entry 7). Finally, $N$-methyl aniline $\mathbf{8 i}$ readily participated in the hydroamination reaction giving the $N$-methyl enamide $9 \mathbf{i}$ in near quantitative yield (entry 8).

(13) Crystal data for 9a: $\mathrm{C}_{12} \mathrm{H}_{14} \mathrm{~N}_{2} \mathrm{O}_{2}, \mathrm{M}=218.25$, monoclinic, I2/a; $a=$ $16.015(3) b=5.4583(9), c=25.143(5) \AA, \beta=99.848(2)^{\circ}, V=2165.5(7) \AA^{3}$. $D_{\text {calc }}=1.339 \mathrm{~g} / \mathrm{cm}^{-3} ; \mu \square(\mathrm{Mo}-\mathrm{K} \alpha)=0.093 \mathrm{~mm}^{-1} ; \lambda=, 0.71073 \AA, \mathrm{T}=150(2)$ $\mathrm{K} ; 12077$ total reflections, 3283 unique data $\left(R_{\text {int }}=0.0277\right)$; Solved by direct methods and refined on $F^{2}$ values to give $R 1=0.0428$. See supporting information for further details. 
TABLE 1. Substrate scope for the Au(I) catalysed hydroamination of allenamide $\mathbf{5 a} .^{a}$

Entry

The hydroamination reaction was also performed with chiral and acyclic allenamides and the results are shown below in Table 2.

TABLE 2. Variation of the allenamide in the Au(I) catalysed hydroamination reaction. ${ }^{a}$

\begin{tabular}{|c|c|c|c|c|}
\hline Entry & Substrate & Aniline & Product $^{b}$ & ${\text { Yield }[\%]^{c}}^{c}$ \\
\hline 1 & & $8 a$ & & 79 \\
\hline 2 & & $8 f$ & & 91 \\
\hline 3 & $\mathrm{Bz}^{-\stackrel{\mathrm{Me}}{\mathrm{N}}}$ & $8 f$ & & 46 \\
\hline 4 & $\mathrm{Bz}^{-\mathrm{N}^{\mathrm{N}} / / 7}$ & $8 g$ & e $\quad H$ & 47 \\
\hline
\end{tabular}

${ }^{a}$ See experimental section for procedure; ${ }^{b}$ data for all new compounds is contained within the supplementary information; ${ }^{c}$ Isolated yields

Chiral allenamide 5b successfully underwent hydroamination with both aniline 8a and 2-iodoaniline $8 \mathbf{f}$ giving the chiral enamides $\mathbf{1 0 a}$ and $\mathbf{1 0 b}$, respectively. No epimerization was observed, but slightly reduced yields as compared to the achiral allenamide $\mathbf{5 a}$ was seen (entries 1 and 2). The acyclic allenamide 7 also underwent hydroamination with anilines $\mathbf{8 f}$ and $\mathbf{8 g}$. A crude ${ }^{1} \mathrm{H}$ NMR of enamides 11a and 11b indicated full conversion to the desired products, however the isolated yields were modest at best and we have attributed this to product degradation during purification.

A mechanistic rationale for this transformation is outlined in Scheme 5.

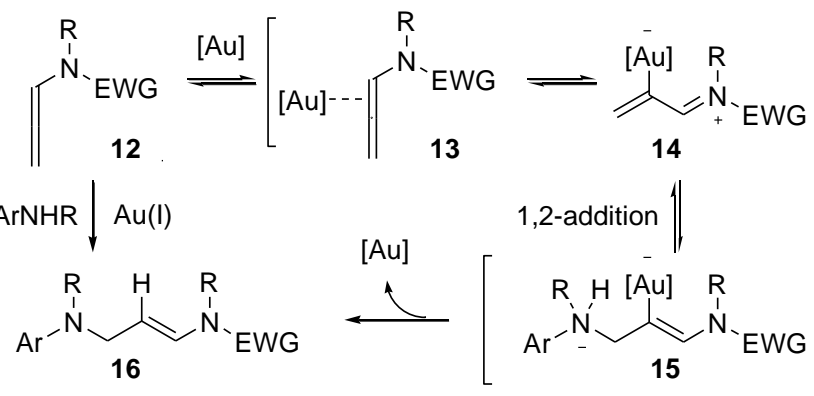

SCHEME 5. Mechanistic rationale for the hydroamination reaction.

We believe that the cationic $\mathrm{Au}(\mathrm{I})$ salt activates the allenamide $\mathbf{1 2}$ to give an conjugated $N$-acyl iminium intermediate species 14. This can undergo either 1,2- or 2,3addition by a suitable nucleophile. In the case at hand the aniline derivatives undergo 1,2-addition giving 15 which can then undergo protodemetallation to yield the observed $E$ enamide 16.

In summary, we have disclosed an $\mathrm{Au}(\mathrm{I})$ catalysed protocol for the intermolecular hydroamination of allenamides. The reaction is facile, high yielding and stereoselectively gives the $E$-enamide products. The products of this reaction, allylamino enamides, have the potential to be valuable building blocks in organic synthesis since they contain two vital functionalities, allyl amines and enamides, within one framework. The chemistry of this building block, the mechanistic insights and the addition of other nucleophilic species to the $\mathrm{Au}$ activated conjugated $\mathrm{N}$-acyl iminium species are currently being studied in our group and will be reported on in due course.

\section{Experimental section $^{14}$}

Representative hydroamination method with allenamide 5a. To a solution of the allenamide 5a (63 mg, 1.05 equiv., $0.50 \mathrm{mmol})$ in dichloromethane $(3.00 \mathrm{~mL})$ at room temperature was added the aniline derivative (1.05 equiv.) followed by $\mathrm{AuPPh}_{3} \mathrm{OTf}$ (from $\mathrm{AuClPPh}_{3}[12.40 \mathrm{mg}, 5.00$ $\mathrm{mol} \%, 0.025 \mathrm{mmol}]$ and AgOTf $[6.60 \mathrm{mg}, 5 \mathrm{~mol} \%, 0.025$ $\mathrm{mmol}]$ ) and the resultant solution stirred for up to $1 \mathrm{~h}$ at room temperature (monitored by tlc). The resultant reaction mixture was then filtered through a plug of Celite ${ }^{\circledR}$ and the crude mixture purified by column chromatography (ethyl acetate/petroleum ether mixture as indicated). 9a was obatined

(14) Full experimental details and compound data are available in the supporting information 
as a pale yellow solid $\left(\mathrm{R}_{f}=0.42\right)(93 \mathrm{mg}, 86 \%$, MP $89-91$ ${ }^{\circ} \mathrm{C}$ ); [Found (ES): $\mathrm{MNa}^{+}, \mathrm{C}_{12} \mathrm{H}_{14} \mathrm{~N}_{2} \mathrm{O}_{2}, 241.0944$, requires $\mathrm{MNa}^{+}$241.0953]; IR (solution, $\mathrm{CHCl}_{3}$ ) 3441, 3012, 1759, $1673,1602,1504,1482,1417,1250 \mathrm{~cm}^{-1} ;{ }^{1} \mathrm{H}$ NMR (400 $\left.\mathrm{MHz} ; \mathrm{CDCl}_{3}\right) \delta 7.18(\mathrm{t}, J=8.4 \mathrm{~Hz}, 2 \mathrm{H}), 6.91(\mathrm{~d}, J=14.0 \mathrm{~Hz}$, $1 \mathrm{H}), 6.72(\mathrm{t}, J=7.6 \mathrm{~Hz}, 1 \mathrm{H}), 6.62(\mathrm{~d}, J=7.6 \mathrm{~Hz}, 2 \mathrm{H}), 4.96$ (dt, $J=6.4,14.0 \mathrm{~Hz}, 1 \mathrm{H}), 4.42(\mathrm{dd}, J=8.0,9.2 \mathrm{~Hz}, 2 \mathrm{H}), 3.80$ $(\mathrm{d}, J=6.4 \mathrm{~Hz}, 2 \mathrm{H}), 3.73(\mathrm{bs}, 1 \mathrm{H}), 3.69(\mathrm{t}, J=8.0 \mathrm{~Hz}, 2 \mathrm{H}) ;{ }^{13} \mathrm{C}$ NMR (100 MHz; $\left.\mathrm{CDCl}_{3}\right) \delta$ 155.3(C), 147.8(C), 129.3(CH), 126.4 (CH), 117.8(CH), 113.1(CH), 107.7 (CH), 62.2 $\left(\mathrm{CH}_{2}\right)$, 43.8 $\left(\mathrm{CH}_{2}\right), 42.5(\mathrm{CH})$.

Representative hydroamination method with allenamide 5b. To a solution of the allenamide $\mathbf{5 b}(50 \mathrm{mg}, 1.00$ equiv., $0.232 \mathrm{mmol})$ in dichloromethane $(2.00 \mathrm{~mL})$ at room temperature was added the aniline derivative (1.05 equiv.) followed by $\mathrm{AuPPh}_{3} \mathrm{OTf}$ (from $\mathrm{AuClPPh}_{3}[5.80 \mathrm{mg}, 5.00$ mol\%, $0.012 \mathrm{mmol}$ ] and AgOTf [3.00 mg, $5 \mathrm{~mol} \%, 0.012$ mmol]) and the resultant solution stirred for up to $1 \mathrm{~h}$ at room temperature (monitored by tlc). The resultant reaction mixture was then filtered through a plug of Celite ${ }^{\circledR}$ and the crude mixture purified by column chromatography (ethyl acetate/petroleum ether mixture as indicated). 10a was obtained as a colourless oil $\left(\mathrm{R}_{\mathrm{f}}=0.5\right)(48 \mathrm{mg}, 68 \%) ;[\alpha]_{\mathrm{D}}{ }^{20}=$ 26.0 (c 1.00, $\mathrm{CHCl}_{3}$ ) [Found (ES): $\mathrm{MNa}^{+}, \mathrm{C}_{19} \mathrm{H}_{20} \mathrm{~N}_{2} \mathrm{O}_{2}$, found 331.1413, requires $\mathrm{MNa}^{+} 331.1422$ ]; IR (solution, $\mathrm{CHCl}_{3}$ ) 3014, 2926, 1755, 1670, 1503, 1413, 1310, 1238, $1206 \mathrm{~cm}^{-1}$; ${ }^{1} \mathrm{H}$ NMR $\left(400 \mathrm{MHz} ; \mathrm{CDCl}_{3}\right) \delta 7.35-7.26(\mathrm{~m}, 3 \mathrm{H}), 7.20(\mathrm{t}, J$ $=8.0 \mathrm{~Hz}, 2 \mathrm{H}), 7.15-7.13(\mathrm{~m}, 2 \mathrm{H}), 6.84(\mathrm{~d}, J=14.4 \mathrm{~Hz}, 1 \mathrm{H})$, $6.74(\mathrm{t}, J=7.6 \mathrm{~Hz}, 1 \mathrm{H}), 6.66(\mathrm{~d}, J=8.4 \mathrm{~Hz}, 2 \mathrm{H}), 5.22(\mathrm{dt}, J=$ 6.4, $14.4 \mathrm{~Hz}, 1 \mathrm{H}), 4.27-4.17(\mathrm{~m}, 3 \mathrm{H}), 3.87-3.83(\mathrm{~m}, 2 \mathrm{H})$, $3.21-3.18(\mathrm{~m}, 1 \mathrm{H}), 2.81-2.76(\mathrm{~m}, 1 \mathrm{H}) ;{ }^{13} \mathrm{C}$ NMR $(100$ $\mathrm{MHz}_{\left.\mathrm{CDCl}_{3}\right)} \delta$ 155.8(C), 147.8(C), 135.2(C), 129.3(CH), 129.3(CH), 129.0(CH), 127.4(CH), $125.3(\mathrm{CH}), 117.9(\mathrm{CH})$,
113.2(CH), $\quad 108.3(\mathrm{CH}), \quad 66.7\left(\mathrm{CH}_{2}\right), \quad 55.0(\mathrm{CH}), \quad 44.2\left(\mathrm{CH}_{2}\right)$, 36.3 $\left(\mathrm{CH}_{2}\right)$.

Representative hydroamination method with allenamide 7. To a solution of the allenamide 7 (50 $\mathrm{mg}, 1.00$ equiv., 0.289 $\mathrm{mmol})$ in dichloromethane $(3.00 \mathrm{~mL})$ at room temperature was added the aniline derivative (1.05 equiv.) followed by $\mathrm{AuPPh}_{3} \mathrm{OTf}$ (from $\mathrm{AuClPPh}_{3}[7.20 \mathrm{mg}, 5.00 \mathrm{~mol} \%, 0.014$ mmol] and AgOTf [3.70 $\mathrm{mg}, 5 \mathrm{~mol} \%, 0.014 \mathrm{mmol}])$ and the resultant solution stirred for up to $1 \mathrm{~h}$ at room temperature (monitored by tlc). The resultant reaction mixture was then filtered through a plug of Celite ${ }^{\circledR}$ and the crude mixture purified by column chromatography (ethyl acetate/petroleum ether mixture as indicated). 11a was obtained as a yellow oil $\left(\mathrm{R}_{\mathrm{f}}=0.35\right) \quad(52 \mathrm{mg}, 46 \%)$; [Found (ES): $\mathrm{MNa}^{+}, \mathrm{C}_{17} \mathrm{H}_{17} \mathrm{IN}_{2} \mathrm{O}$, found 331.415.0271, requires $\mathrm{MNa}^{+}$415.0283]; IR (solution, $\left.\mathrm{CHCl}_{3}\right) 3441,3011,1638,1590,1506,1389,1069 \mathrm{~cm}^{-1} ;{ }^{1} \mathrm{H}$ NMR (400 MHz; $\mathrm{CDCl}_{3}$ ) (mixture of rotamers) $\delta 7.64(\mathrm{~d}, J=$ $7.6 \mathrm{~Hz}, 1 \mathrm{H}), 7.49-7.40(\mathrm{~m}, 5 \mathrm{H}), 7.20(\mathrm{t}, J=7.2 \mathrm{~Hz}, 1 \mathrm{H})$, $6.78(\mathrm{bs}, 1 \mathrm{H}), 6.50(\mathrm{bs}, 1 \mathrm{H}), 6.48-6.44(\mathrm{~m}, 1 \mathrm{H}), 5.16(\mathrm{bs}$, $1 \mathrm{H}), 4.17$ (bs, $1 \mathrm{H}), 3.77-3.75(\mathrm{~m}, 2 \mathrm{H}), 3.27(\mathrm{bs}, 3 \mathrm{H}) ;{ }^{13} \mathrm{C}$ NMR (100 $\mathrm{MHz}_{\mathrm{CDCl}_{3}}$ ) (mixture of rotamers) $\delta 170.9(\mathrm{C})$, 146.4(C), 139.1(CH), 135.7(C), 133.0 (CH), 129.4(CH), $128.7(\mathrm{CH}), 128.0(\mathrm{CH}), 119.0(\mathrm{CH}), 110.8(\mathrm{CH}), 105.7(\mathrm{CH})$, 85.7(C), 44.1 $\left(\mathrm{CH}_{2}\right), 30.4\left(\mathrm{CH}_{3}\right)$.

Acknowledgments. The author thanks Loughborough University for financial support.

Supporting Information Available. Experimental procedures, ${ }^{1} \mathrm{H}$ and ${ }^{13} \mathrm{C}$ NMR spectra, characterization for 9a-9i, 10a, b, 11a,b and the crystallographic data for $\mathbf{9 a}$.. This material is available free of charge via the Internet at http://pubs.acs.org. 